\title{
A LITERATURA COMO VISÃO DO NOVO MUNDO*
}

Roberto de Oliveira Brandão**

RESUMO: A presente análise procura mostrar como os primeiros colonizadores que escreveram sobre o Brasil viram-no a partir das suas próprias experiências, projetos e valores. Se no início também os nossos poetas assumiram a identidade cultural e literária da Metrópole, com o tempo desenvolveriam eles uma nova sensibilidade, associada a novos modos de ver e sentir suas relações com o meio cujas conseqüências se refletiriam na poesia aqui produzida.

Palavras-chave: Literatura e colonização, poesia brasileira.

\section{COLOCAÇÃO DO PROBLEMA}

O problema da formação da literatura brasileira tem um interesse especial por tocar em aspectos da criação literária em sua dupla relação: com a realidade (entendida como ser bruto, desconhecido ou ainda não incorporado a um sistema próprio de significado) e com a cultura (como o conjunto dos valores e crenças de uma comunidade). Nesse sentido é que vamos rastrear, nos primeiros textos aqui produzidos, a presença de algumas imagens que em verdade revelam a perspectiva particular com que éramos visto a partir do descobrimento.

Nossa análise abrange aquilo que Antonio Candido chama de "manifestações literárias", isto é, expressões anteriores à existência de uma literatura brasileira propriamente dita, já que, de acordo com sua concepção de "sistema literário", para que se tenha literatura é necessário haver "continui-

* Conferência proferida no dia $1^{\circ}$ de abril de 1996, como uma das provas do Concurso para Professor Titular junto ao Departamento de Letras Clássicas e Vernáculas da Faculdade de Filosofia, Letras e Ciências Humanas.

* Professor de Literatura Brasileira na Universidade de São Paulo. 
dade ininterrupta de obras e autores cientes quase sempre de integrarem um processo de formação literária"', fato que, segundo o crítico, só se poderá reconhecer no Brasil a partir da segunda metade do século XVIII, com o Arcadismo. Antes disso, as obras aqui produzidas estavam comprometidas com a experiência literária e cultural da metrópole, refletindo, portanto, o sistema da literatura portuguesa ${ }^{2}$

\section{COMO O COLONIZADOR VIU A COLÔNIA}

O descobrimento do Brasil se fez sob os olhares da retórica. Quando Caminha, no começo da Carta, diz que não pretende "nem aformosear nem afear", mas apenas pôr "o que viu e lhe pareceu", estava obedecendo às normas descritivas próprias do seu texto. Dito de outro modo, o propósito de se manter neutro diante da realidade era imposição do gênero em que escrevia, segundo o modelo de visibilidade renascentista a serviço das grandes navegações e da expansão colonial. Não podemos nos esquecer que a viagem de Cabral, como a de Colombo no âmbito da América espanhola, se inseriam no projeto colonizador europeu, implicando as mesmas motivações e expectativas. Com tal projeto, de que a Carta não era senão um instrumento retórico-literário, os portugueses aportaram às nossas praias. Como disse um historiador da literatura hispanoamericana [Enrique Anderson IMBERT] - e que vale também para a nossa -:

1 Formação da Literatura Brasileira, I, p. 27. Como elementos da constituição e do funcionamento do "sistema literário", as noções de "continuidade" e de "tradição" se completam na visão do crítico, ou seja: "Quando a atividade dos escritores de um dado periodo se integra em tal sistema, ocorre outro elemento decisivo: a formação da continuidade literária, - espécie de transmissão da tocha entre corredores, que assegura no tempo o movimento conjunto, definindo os lineamentos de um todo. É uma tradição, no sentido completo do termo isto é, transmissão de algo entre os homens, e o conjunto de elementos transmitidos, formando padrões que se impõem ao pensamento ou ao comportamento, e aos quais somos obrigados a nos referir, para aceitar ou rejeitar. Sem esta tradição não há literatura, como fenômeno de civilização (Ibidem, p. 26)

2 Em sentido inverso, alguns dos primeiros históriadores brasileiros do século XIX consideram os autores nascidos na colônia, incluindo os árcades, como pertencentes à literatura portuguesa. Vejam-se o Curso de Literatura Portuguesa e Brasileira, de Sotero dos Reis (Maranhão, 1866), e o Curso Elementar de Literatura Nacional (Rio de Janeiro, 1862), de Joaquim Caetano Fernandes Pinheiro. 
"Conquistadores y misioneros trajeron esa literatura al nuevo mundo. La trajeron en sus barcos y en sus cabezas"3.

O fato é que a própria língua trazida pelos colonizadores continha já os limites e as regras do que podia ou devia ser visto e nomeado, isto é, uma ontologia, uma ética e uma retórica. $\mathrm{Na}$ Carta encontramos muitos indícios desse fenômeno. Veja-se uma das primeiras cenas em que indígenas entram na embarcação onde estão o capitão e alguns marinheiros, ao que comenta o cronista, significativamente admirado:

"Mas nem sinal de cortesia fizeram, nem de (querer) falar ao capitão; nem a ninguém"

$\mathrm{Na}$ verdade, a estranheza expressa pela adversativa tinha sua razão de ser, sobretudo levando-se em conta as normas de conduta do civilizado. Essas normas prescreviam que uma pessoa, ao entrar em local desconhecido, devia cumprimentar os presentes, em especial os mais importantes, o que implicava que os indígenas percebessem e distinguissem a hierarquia de cada membro daquele grupo, fato que não omitiu Caminha ao exclarecer que o capitão estava "sentado em uma cadeira, [tendo] aos pés uma alcatifa por estrado; e bem vestido, com um colar de ouro mui grande, ao pescoço", ao passo que os outros, entre os quais o próprio escrivão, encontravam-se, simplesmente, "sentados no chão, nessa alcatifa"

A distinção entre "sentar-se numa cadeira" e "sentar-se no chão", indicativos da diferença social e funcional entre "capitão" e "marinheiros" não era certamente percebida pelos indígenas, como parece esperar o escrivão. E este não supõe que a ausência de cumprimento pudesse indicar "outro modo de agir", mas a vê como "falta" de um padrão necessariamente único.

Em outro lugar, faz Caminha uma interpretação que revela mais o desejo e a ambição dos colonizadores do que os objetivos reais daquele indígena. Segundo ele, o nativo:

“... fitou o colar do Capitão, e começou a fazer acenos com a mão em direção à terra, e depois para o colar, como se quisesse dizer-nos que havia ouro na terra. E também olhou para um castiçal de prata e assim mesmo acenava para a terra e novamente para o castiçal, como se lá também houvesse prata!"

3 IMBERT, Enrique Anderson. Historia de la literatura hispanoamericana. II, p. 19. 
Em outra cena semelhante, completa-se aos nossos olhos o significado - no mínimo singular -, sobre os supostos gestos do indígena. Diz o cronista:

"Viu um deles umas contas de rosário, brancas; fez sinal que lhas dessem, e folgou muito com elas, e lançou-as ao pescoço; e depois tirou-as e meteu-as em volta do braço, e acenava para a terra e novamente para as contas e para o colar do Capitão, como se dariam ouro por aquilo"

Se, diante da ausência de saudação manifestava o cronista sua estranheza pelo comportamento "pouco educado" do indígena, já que lhe faltavam as marcas desse ritual da civilização, agora ele "vê" nos seus gestos um significado que em verdade denuncia seu interesse de colonizador. A suposta afirmação de que "havia ouro na terra". ("como se havia ouro na terra"), se completa com outra, a de que "dariam ouro por aquilo" ("como se dariam ouro por aquilo"). O curioso é que o próprio escrivão parece perceber as motivações implícitas em sua fala, confessando-nos:

"Isto tomávamos nós nesse sentido, por assim o desejarmos!"

Como vemos, entre "ingênuas" e "sinceras" (mas certamente nem tanto), tais palavras revelam que o cronista desloca para os gestos do nativo significados que em verdade estão na sua cabeça de colonizador, para retomar a expressão de Enrique Anderson Imbert, citada há pouco.

\section{ALGUMAS REFLEXÕES, ANTES DE PROSSEGUIRMOS}

Levando-se em conta o que vimos acima, digamos, a título de hipótese, que a compreensão do que iria se constituir na literatura brasileira precisa levar em conta três ordens de fatores inter-relacionados: fatores históricos, lingüísticos e literários, entendidos, respectivamente, como:

a) uma experiência humana desenvolvida num contexto geográfico, social e cultural assumidos como próprios;

b) um idioma com traços semânticos, prosódicos, sintáticos e morfológicos ajustados à expressão dessa experiência;

c) um conjunto de formas literárias capazes de conferir substância simbólica àquela experiência referida no primeiro item. 
em Portugal, ou seja, expressam crenças e valores veiculados por idioma e formas literárias inteiramente sintonizados com as tradições históricas e estéticas portuguesas. Para que se pudesse reconhecer algo de novo face a essa origem, seria necessário um longo processo, pelo qual a língua trazida pelos colonizadores fosse desenvolvendo uma competência e um desempenho tais que pudesse expressar as transformações ocorridas na colônia.

Assim posto, podemos imaginar a passagem da literatura portuguesa para a brasileira como resultado do permanente esforço produzido pelos falantes da língua portuguesa identificados com o Brasil para manifestar sua experiência histórica, social, lingüística e literária como algo próprio e, portanto, distinto da sua origem européia.

A esse respeito, lembremos outra vez Antonio Candido, para quem, cmbora o "equívoco" estimulado pelos primeiros críticos estrangeiros de nossa literatura, que a concebiam como "expressão da realidade local"4, o critério era válido nessa fase histórica na medida em que, como diz ele: " $O$ contelido brasileiro foi algo positivo, mesmo como fator de eficácia estética, dando pontos de apoio à imaginação e músculos à forma"s Notemos, embora apenas de passagem, que Machado de Assis, na segunda metade do século XIX, já havia discutido o problema em seu estudo "Instinto de nacionalidade" (1872).

Reconhecia o romancista o empenho com que nossos autores haviam buscado "vestir-se com as cores do país" "Não há dúvida", dizia ele, "que uma literatura, sobretudo uma literatura nascente, deve principalmente alimentar-se dos assuntos que lhe oferece a sua região"

Ressalte-se que Machado justifica a representação do particular nacional apenas no caso de uma literatura "nascente" Entretanto, com base em sua experiência ficcional, e com o conhecimento do que se fizera antes dele, vai além, formulando uma idéia avançada para seu meio e tempo: a de que, mais importante que assuntos locais, seria necessário ao escritor "certo sentimento intimo, que o torne homem de seu tempo e de seu país, ainda quando trate de assuntos remotos no tempo e no espaço"“. Dito de outro modo, e recorrendo às idéias de Adorno sobre a relação entre lírica e socicdade, podemos diz que esta "não deve ser trazida de for a às formaçôes líricas, mas ser haurida da rigorosa intuição delas mesmas"

4 Op. cit., I, p. 27.

5 Op. cit., I, p. 31.

6 "INSTINTO DE NACIONALIDADE" In OC., III, p. 804.

7 "LÍRICA E SOCIEDADE" In Os Pensadores, p. 194. 
Isso explica a sensação que temos de que a literatura e também a arte têm autonomia face ao real.

Como se verificará adiante, as obras aqui analisadas ficam aquém da perspectiva aberta por Machado, cujos exemplos, em verdade, foi ele o primeiro a produzir entre nós.

\section{A POESIA EMPENHADA DE ANCHIETA}

Se, cronologicamente, Anchieta foi o primeiro a fazer poesia na Colônia, do ponto de vista que estamos analisando, isto é, o da literatura brasileira, sua produção representa, não a criação da nossa literatura, como querem alguns $\operatorname{críticos}^{8}$, mas o desdobramento do processo de colonização, um de seus meios, como o foram os autos e a gramática da língua tupi, que tinham por objetivo principal a catequese.

Como os cronistas eram movidos pelo projeto de conquista, derivando daí seu modo de ver e entender a nova terra, os jesuítas procuraram modificar a mentalidade e os hábitos dos indígenas, buscando moldá-los, pela persuasão, aos seus padrões de crenças e valores. Nesse sentido, mais que "brasileira" propriamente dita, a obra de Anchieta significa antes a inserção do Brasil na tradição cristã, como a Prosopopéia (1601), de Bento Teixeira Pinto, iria dar início entre nós à longa influência clássico-camoniana ${ }^{9}$

Vejamos o poema "Do Santíssimo Sacramento" cujas estruturas poéticas, inspiração e imagens têm origem no contexto medieval europeu, não no Brasil do século XVI. Sua vigência aqui representa o transplante de um sistema acabado sem outra finalidade que a de se impor como valor religioso e formativo.

8 Wilson Martins lembra algumas opiniōes sobre a poesia de Anchieta: segundo ele, Melo Moraes Filho o julgava "o genuino criador da literatura nacional", juízo partilhado pelo Pe. Hélio Abranches Viotti, o prefaciador da edição de suas poesia, enquanto que para Silvio Romero o jesuíta seria um "simples precursor" Para o próprio autor do estudo, Anchieta teria realizado "as primeiras tentativas de poesia religiosa verificadas no Brasil e até as primeiras tentativas de poesia", ressaltando, contudo, que "a poesia lhe serviu de intrumento politico no sentido amplo da palavra, foi-lhe um meio de conquistar para a sua própria ideologia os selvagens brasileiros do século XVI' (História da Inteligência Brasileira, I, p. 28 segs).

9 Antonio Candido, na introdução aos Capitulos de História Colonial, de Sérgio Buarque de Holanda, lembra que o autor, ao estudar o poema de Bento Teixeira, "analisa bem o seu corte renascentista, indicando o sistema de tópicos e alusões mitológicas que servem para incorporar o Brasil ao quadro consagrador da celebração épica." (p. 15). 
n. 22 , p. $201-219,1996$.

Estudando sua composição, Leodegário Azevedo Filho mostra como a redondilha maior, com que é feito o poema - isto é, versos de 7 sílabas ou de medida velha -, era "o metro mais popular da poesia peninsular do fim da Idade Média" 10 , ao contrário do decassílabo ou verso de medida nova. Por outro lado, poderíamos dizer também que esta última, ao permitir maior variedade de ritmos, se ajustaria melhor à auto-afirmação própria do homem renascentista.

Os estudiosos de Anchieta apontam também o fato de as raizes de sua poesia passarem ao largo das modificações temáticas e formais que iam sendo introduzidas em Portugal, desde a viagem que Sá de Miranda (1481-1558) fez à Itália e Espanha (1521), levando a Portugal as novidades poéticas clássicorenascentistas. Ao analisar sua lírica, Alfredo Bosi observa que " $A$ linguagem de A Santa Inês' 'Do Santíssimo Sacramento' e 'Em Deus, meu Criador molda-se na tradição medieval espanhola e portuguesa;". E completa o crítico, apontando a relação entre suas formas breves e o despojamento material que já não se coadunava com o homem da Renascença: "em metros breves, da 'medida velha Anchieta traduz a sua visão do mundo ainda alheia ao Renascimento e, portanto, arredia em relação aos bens terrenos" $"$

No mesmo sentido, Wilson Martins diz que "Anchieta é escritor de transição entre a Idade Média e o Barroco, sem revelar qualquer assimilação das técnicas difundidas pelo Renascimento"12.

Se, no que concerne à sua alegada simplicidade, poderíamos dizer que Anchieta acaba se ajustando à rusticidade do meio, ou, como sustenta Leodegário Azevedo, ao dizer que, "no Brasil do século XVI, naturalmente tinha o poeta que ser primitivo, simples e popular, para atingir os seus objetivos de catequese" ${ }^{\text {"13 }}$, o fato é que essa simplicidade se revela altamente elaborada para dar conta das verdades religiosas que quer transmitir. $\mathrm{Na}$ verdade, o poeta mostra, por um lado, uma divindade sem ameaças, sempre disposta a perdoar e, por outro, um ser humano cujo maior pecado é pertencer ao mundo da matéria e dos sentidos, a partir dos quais deve - e pode ser elevado, pelo amor e não pelo entendimento, à busca dos bens divinos.

Ai me parece estar a "simplicidade" do poeta de raizes medievais, simplicidade como elemento formal que configura a relação entre criador e criatura, transformada em tema. Em momento algum vemos na poesia de

10 Anchieta, a Idade Média e o Barroco, p. 37.

11 História Concisa, la. ed., p. 23.

12 História da Inteligência Brasileira, I, p. 27.

13 Anchiera, a ldade Média e o Barroco, p. 56. 

n. 22, p. 201-219, 1996.

Anchieta uma atitude desafiadora e racional do ser humano argumentando com seu criador, como aparece, por exemplo, em Gregório:

Se uma ovelha perdida e já cobrada

Glória tal e prazer tão repentino

Vos deu, como afirmais na sacra história

Eu sou, Senhor, a ovelha desgarrada,

Cobrai-a; e não queirais, pastor divino,

Perder na vossa ovelha a vossa glória.

Ao contrário, o poema de Anchieta é expositivo, direto. Mas ele parte de cima, de algo já estabelecido, de um símbolo da fé cristã: o "pão", para, aos poucos, ir descendo, por analogia ou modulação do sentido, a ponto de fundir os aspectos "sagrados" às situações reconhecidamente humanas: "divino bocado", "manjar de lutadores", "deleite de namorados", etc. Assim, o divino e o humano tornam-se intercambiáveis, como se o poeta criasse, ao nível poético, a identidade necessária às matérias de fé. Essa solução se aplica aos dogmas cristãos: o sacramento como renovação da presença divina ("se nos dá no santo altar/ cada dia"), a morte de Cristo como prova do amor de Deus ("que Deus padre cá mandoul e por nós na cruz passoul crua morte"), a comunhão como meio de salvação ("co gosto deste pão/ deixam a deleitação/ transitória"), o mistério da união entre Deus e homem em Cristo ("pois debaixo do que vemos./ estar Deus $e$ homem cremos./ sem mudaça"), enfim, as verdades da fé vão tomando dimensão terrena, próxima e possível e como tais são tratadas.

Esses elementos mostram como a poesia de Anchieta está enraizada na cultura e na literatura européias medievais, não podendo, a rigor, ser considerada expressão da literatura brasileira do século XVI no sentido de expressar simbólica e formalmente uma experiência própria da terra e campartilhada por seus habitantes.

\section{DA POÉTICA CLÁSSICA AO SENTIMENTO DA TERRA}

Se hoje, num mundo em que as diferenças individuais são constantemente estimuladas, sabe-se que o processo de afirmação da identidade cultural depende de um movimento duplo de reação e convivência com outros valores, sabe-se também que, para que haja esse movimento, é necessário que alguma forma prática de vida seja sentida, aceita e valorizada, embora 
nem sempre conscientemente, como específica e partilhada pelo grupo social. A representação simbólica desse sentimento dá-lhe consciência e reforça a união dos membros do grupo.

Ao considerarmos os primeiros poetas que escreveram no Brasil verificamos que eles viam a terra como objeto de admiração, mas não como fonte de inspiração poética, pois o repertório dos temas possíveis já "havia sido dado pelos fundadores da cultura clássica" Manuel Botelho de Oliveira, em 1705, expressa bem essa idéia:

"Nesta América, inculta habitação antigamente de bárbaros, mal se podia esperar que as Musas se fizessem brasileiras"14

Essa referência ao surgimento de uma poesia brasileira, embora sob ressalva do autor, precisa ser relativizada ainda mais na medida em que, em sua própria prática criativa, mostra o profundo enraizamento nos modelos europeus. Em sua poesia ele usa, por exemplo, todo o arsenal metafórico barroco (cravo por boca, cristal por água, etc. e a representação das estações do ano como elas ocorrem na Europa onde maio é primavera e dezembro, inverno. Ressalte-se que o poeta escrevia na Bahia.

Em terra distante da civilização e dos padrões clássicos, como era o Brasil colônia, apenas cumpria aos nossos poetas imitar os modelos consagrados. Como Anchieta buscara inspiração e formas poéticas no mundo medieval e nos dogmas cristãos, Bento Teixeira Pinto, autor do primeiro poemeto épico aqui composto, a Prosopopéia (1601), as buscou nos poetas então conhecidos, especialmente Camões.

O poema de Bento Teixeira surge menos de três décadas depois de Os Lusiadas (1572), reproduzindo-lhe, contudo, apenas uma pálida imagem sintático-estrófica, além dos recursos mitológicos que toda épica devia ter. No prólogo ele declara sua filiação poética: Horácio, e deste toma a analo-

14 Misica do Pamaso, p. 3. Interessante é que, na passagem daqueles poemas em que o poeta trata de assuntos típicos da poesia barroca européia para poemas em que trata de assuntos locais, ocorre uma mudança de tom, produzindo a impressão de que nossos poetas coloniais apresentam melhor desempenho nas composiçōes em que eles conservam o mesmo conjunto "forma/tema" dos poemas de origem. Isso certamente se deve ao fato de que a apropriação da relação conteúdo/técnica poética se fez a partir de conjuntos fechados, isto é, em que o "tema" e a "forma", a "intuição" e a "expressão", mantiveram-se unidos na passagem das fontes européias para suas reproduções nacionais. Pelo contrário, toda vez que se tentou aplicar uma forma elaborada em decorrência das necessidades expressivas européias, adaptando-a aos temas brasileiros, a sensação que resultou foi de desarmonia, desencontro, queda de tom, como ocorre no poema Ilha de Maré. 
gia entre poesia e pintura - o "ut pictura poesis" - e a idéia clássica do trabalho como meio de atingir a perfeição. Alude modestamente ao próprio texto como um "rascunho", a que espera não falte "a tinta do favor" de seu homenageado, o governador de Pernambuco, Jorge de Albuquerque Coelho.

$\mathrm{O}$ que chama nossa atenção é exatamente sua falta de raízes no Brasil, que se restringem à figura do donatário, "...em quem se esmaltal $A$ Estirpe d'Albuquerques excelente", cantado como herói universal, e uma descrição do porto de Pernambuco, feita com retalhos da astronomia mitológica das épicas clássicas.

A máscara de modéstia que introduz o poema é uma tópica antiga que Curtius, na Literatura Européia e Idade Média Latina" chama "celeiro de provisões" O recurso não esconde o vaidoso desejo de superar os que o precederam, simbolizados pela "Lácia e Grega lira" O governador surge como "firme muro" protetor "da Fé [e] da Cara Pátria", os mesmos conceitos que os cronistas cobravam dos nossos indígenas, ao constatarem que sua língua não tinha as letras $F, L$ e $R$, não tendo, portanto, nem "fé", nem "lei", nem "rei" (Gândavo"16; Gabriel Soares de Sousa ${ }^{17}$ ). Longe estavam eles (e sua época) de compreenderem que cada idioma recorta o mundo de uma maneira peculiar, ou, para dizer com Sapir, que:

“... a língua não existe isolada de uma cultura, isto é, de um conjunto socialmente herdado de práticas e crenças que determinam a trama das nossas vidas." 18.

A tópica de modéstia será usada também pelos árcades. Basílio da Gama (Uraguay, 1769) invoca a musa para que, juntos, honrassem o "herói" de seu poema (o Marquês de Pombal), por ter promovido o ataque às missões jesuíticas (dos Sete Povos, Rio Grande do Sul e banda oriental do Uruguai). Em primeiro plano, falam mais alto sua formação cultural portuguesa e a obediência de súdito fiel à Metrópole do que sua origem americana:

Musa, honremos o Herói, que o povo rude

Subjugou do Uraguay, e no seu sangue

Dos decretos reais lavou a afronta ${ }^{19}$

15 Literatura Européia e Idade Média Latina, p. 82.

16 Tratado da Províncio do Brasil, p. 181-3.

17 Tratado Descritivo do Brasil, p. 302.

18 A Linguagem, p. 205.

19 Uraguay, I, 6-8. 
Além da ajuda de deuses e musas, a poética tradicional fornecia ainda as fórmulas para expressar a relação de mecenato e vassalagem coloniais. Pertencendo à estirpe dos heróis, era natural que o homenageado de Basílio participasse dos poderes divinos, o que justifica ao poeta buscar também o seu auxílio:

Herói, e Irmão de Herói, saudosa, e triste, Se ao longe a vossa América vos lembra, Protegei os meus versos ${ }^{20}$.

Santa Rita Durão (Caramuru, 1781), menos criativo que Basílio e mais dócil ao modelo épico, usa uma fórmula típica do gênero: ao invocar a ajuda divina, procura engrandecer o objeto de seu canto e, assim, exibi-lo como uma "grande obra":

Santo Esplendor, que do Grão Padre manas

Faze que em ti comece e em ti conclua

Esta grande obra, que por fim foi tua ${ }^{21}$

Nas "Reflexões Prévias e Argumento", que antecedem seu poema, manifesta o desejo de criar uma obra que ombreasse com Os Lusiadas. Emprega um procedimento muito comum desde os cronistas que, para louvar as coisas da terra, as comparavam com as européias, mostrando que as nossas não lhes ficavam devendo em nada. Também Botelho de Oliveira, na "Ilha de Maré" (1705) usou e abusou de hipérboles sobre as virtudes da natureza brasileira. O recurso chegou ao romantismo de Gonçalves Dias ("Nosso céu tem mais estrelas...") e à paródia modernista que lhe fez Murilo Mendes ("Nossas frutas são mais gostosas, mas custam cem mil réis a dúzia"). $\mathrm{Na}$ fala introdutória de Durão, contudo, surge outro motivo para a feitura do poema: o amor da Pátria:

"Os sucessos do Brasil não mereciam menos um Poema que os da India. Incitou-me a escrever este o amor da Pátria." ${ }^{22}$.

Se no poema tal própósito não tem o tratamento que as "Reflexões Prévias..." sugerem, vale como indicação de seu afeto pela terra, que será,

20 Ibid., I, 12-4.

21 Caramuru, I, II, 1-8.

22 Ibid, Prefácio. 
com o tempo, um dos fatores de integração espiritual dos nossos poetas com o espaço físico e geográfico da colônia.

A partir do século XVIII o argumento se faz cada vez mais presente: Botelho de Oliveira, na "Música do Parnaso" (1705), justifica sua obra, senão por ser melhor que a de outros, "para ao menos ser o primeiro filho do Brasil, que faça puiblica a suavidade do metro"23; também Frei Manuel de Santa Maria Itaparica, na "Descrição da Ilha de Itaparica" (1769), declara seus sentimentos à terra de origem: "Cantar procuro, descrever intento/ Em um Heróico verso, e sonoroso,/ Aquela que me deu o nascimento,/ Pátria feliz, que tive por ditoso"24; oito anos depois, Silva Alvarenga, no poema "O Templo de Netuno" (1777), confessaria, ao deixar Lisboa em direção ao Brasil: "o puro amor do pátrio ninho/ Há muito que me acena"2s.

Vejamos agora uma das mais significativas manifestações de afeto pela terra, contida na poesia de Cláudio Manuel da Costa.

\section{A LÍRICA DE CLÁUdIO MANUEL DA COSTA}

A lírica de Cláudio é interessante porque mostra como se vai deslocando o eixo de apreciação do Brasil da perspectiva cultural européia para uma ligação afetiva com a terra. Isso é mais importante na medida em que o poeta está fortemente ligado aos valores culturais e às convenções árcades.

Nascido no Brasil e tendo adquirido aqui suas primeiras experiências, passou alguns anos em Portugal onde estudou leis (Coimbra), mas, sobretudo, assimilou os padrões artísticos da época, e iniciou sua atividade criativa. Voltando ao Brasil, não encontra nem o ambiente cultural nem a realidade convencional que aprendera a admirar na poesia do tempo. Pelo contrário, aqui (entenda-se Minas Gerais do século XVIII) as pessoas só ambicionavam bens materiais, buscando enriquecer com a mineração do ouro. Apesar disso, o poeta está afetivamente ligado à terra que o viu nascer e onde sentiu as primeiras emoções. Nessa situação, escreve poemas como este:

Leia a posteridade, ó pátrio Rio,

Em meus versos teu nome celebrado;

23 Mísica do Parnaso, p. 3.

24 Presença da Literatura Brasileira, I, p. 105.

25 Obras Poéticas, I, p. 267. 
n. 22, p. 201-219, 1996.

Por que vejas uma hora despertado

$O$ sono vil do esquecimento frio:

Não vês nas tuas margens o sombrio,

Fresco assento de um álamo copado;

Não vês ninfa cantar, pastar o gado

$\mathrm{Na}$ tarde clara do calmoso estio.

Turvo banhando as pálidas areias

Nas porções do riquíssimo tesouro

$O$ vasto campo da ambição recreias.

Que de seus raios o planeta louro

Enriquecendo o influxo em tuas veias,

Quanto em chamas fecunda, brota em ouro. ${ }^{26}$

Se o poeta quer eternizar o rio de sua terra é porque acredita que a arte pode resgatar as coisas da ação do tempo. Sua imagem deita raizes em idéias bem clássicas: a) de que a arte é longa e a vida breve; b) de que a memória (Mnemosina) era a mãe das musas; c) de que o canto difundia a grandeza do objeto, como dissera Camões: "Cantando espalharei por toda parte, Se a tanto me ajudar engenho e arte" Por outro lado, o poema se alimenta do sentido espiritualizante da arte clássica, que buscava transcender aos fenômenos físicos e naturais. "A realidade do mundo não passa de ilusão fugaz", pensava-se desde a condenação platônica e a pregação cristã. Petrarca (1304-1374) expressa esse impulso anti-mundano. Recordando sua paixão juvenil, a chama de "erro" ("primo giovenile errore"), precisamente porque: "quanto piace al mondo è breve sogno"

No poema de Cláudio, as imagens positivas da primeira estrofe, enquanto desejo de imortalizar o rio, contrastam com as da segunda estrofe, que podemos chamar "imagens da ausência", pois expressam o sentimento de não encontrar na própria terra nem a paisagem nem as figuras pastoris que admirava na natureza arcádica: "rios de águas cristalinas", "margens frescas e sombrias" "álamos copados", "ninfas", "pastores" "tardes calmas e claras", etc.. Na "Fábula do Riberão do Carmo" chega a transferir para o rio brasileiro a frustração que em verdade é sua. Seu estado emotivo se manifesta pela voz do rio:

26 A Poesia dos Inconfidentes, p. 51. 


\section{Competir não pretendo}

Contigo, ó cristalino

Tejo, que mansamente váis correndo:

Meu ingrato destino

Me nega a prateada majestade,

As ninfas generosas,

Que em tuas praias giram,

Ó plácido Mondego, rigorosas

De ouvir-me se retiram;

Não se escuta a harmonia

Da temperada avena

Nas margens minhas; que a fatal porfia

Da humana sede ordena,

Se atenta apenas o ruído horrendo

Do tosco ferro, que me vai rompendo.

Observa-se que o poeta retoma as imagens do soneto, que, aliás, aparecem também no "Prólogo" das suas Obras:

"A desconsolação de não poder substabelecer aqui as delícias do Tejo, do Lima e do Mondego, me fez entorpecer o engenho dentro do meu berço; mas nada bastou para deixar de confessar a seu respeito a maior paixão. Esta me persuadiu a invocar muitas vezes e a escrever a Fábula do Ribeirão do Carmo, rio o mais rico desta Capitania, que corre, e dava o nome à cidade Mariana, minha Pátria, quando era Vila" 27

Esse texto revela as motivações do poema. Embora não encontre no Brasil as imagens idealizadas da poesia arcádica, reconhece que uma força maior o liga à terra natal, e que o obriga a "confessar... a maior paixão". Em outros termos, não há coerção capaz de anular a sensibilidade do poeta: 1) diante do real semantizado pela emoção; 2) diante das ligações com a terra

27 Note-se que o adjetivo "pátrio" indica, nos autores da época, não os conceitos abstratos hoje entendidos como "pátria" ou "nação", mas a "terra de nascimento". Peter Burke, estudando o surgimento da idéia de pertencer a uma coletividade de língua e território, refere-se a um humanista (Coluccio Salutati) que, no início do século XIV, se definia "um italiano por raça, um florentino por pátria ("gente Italicus, patria Florentinus"). Ver: Peter Burke, A Arte da Coversação, p. 96. 
em que nasceu; 3) diante da língua que ainda não tem termos para expressar um sentimento original.

Entretanto, o compromisso do poeta: com o real, com suas origens e com o idioma, não é tarefa fácil. Cláudio resiste em assumir esse compromisso. Ele fala na "desconsolação" por não encontrar aqui as "delicias do Tejo, do Lima e do Mondego", fato que o teria levado "a entorpecer o engenho" em sua terra. Temos então uma verdadeira auto-crítica poética:

"É infelicidade que haja de confessar que vejo e aprovo o melhor, mas sigo o contrário na execução"

Na verdade, o poeta divide-se em dois: um "eu" ao nível cultural, que se identifica com os valores do colonizador e, portanto, utiliza os símbolos deste; e outro "eu" que, não tendo ainda um sistema simbólico próprio, alimenta-se dos estímulos da realidade bruta, ainda sem significado estético e cultural. Daí a percepção de ausência na realidade brasileira ("não vês nas tuas margens..."), que o poeta preenche com as imagens do desejo ("álamo copado", "ninfas, gado", etc..).

Portanto, se Cláudio quer imortalizar o rio da terra, só poderá fazê-lo através do ato fundador da palavra, que ao nomear o real, o cria para o mundo da poesia e da cultura. É o significado da expressão "despertar $o$ sono vil do esquecimento frio", da primeira estrofe, onde se fundem o despertar e o renascer como instâncias superiores ao sono e à morte ${ }^{28}$.

Se o poeta não encontra na realidade brasileira imagens poéticas é porque estas ainda não tinham sido criadas. Nesse momento, a palavra poética recupera sua primitiva função de um "falar natural", que apreende o particular sensível. Como diria Vico (1794), marcando a diferença entre "razão" ("metafisica racional") e "fantasia" ("metafisica fantástica"):

"Com o entendimento, o homem desenvolve sua mente e compreende as coisas, mas, ao não entendê-las, tira de si mesmo essas coisas e, transformando-as, as inventa" 29

$28 \mathrm{Na}$ poesia moderna esse gesto vivificador é dado pela consciência. É por isso que Ricardo Reis, o cético heterônimo pessoano diz: " $O$ sono é bom pois despertamos delel para saber que é bom..." (In Obra Poética, p. ).

29 "l'uomo con l'intendere spiega la sua mente e comprende esse cose. ma col non intendere egli di sé fa esse cose e, col transformandovisi, lo diventa" (La scienza nuova, I, p. 192). 
É o que faz Cláudio no primeiro terceto. O rio brasileiro é designado de "turvo", adjetivo que deita raizes em duas referências: uma realidade e um valor. No "Prólogo" ele já dissera: "Turva e feia, a corrente destes ribeiros, primeiro que arrebate as idéias de um Poeta, deixa ponderar a ambiciosa fadiga de minerar a terra, que lhe tem pervertido as cores"

Portanto, o rio brasileiro é "turvo" porque suas águas são revolvidas no ato da mineração, o que, para a poética do tempo, não seria nada poético, uma vez que implicava em puro interesse material. Mas, se nem o real nem sua expressão lingüística pudessem ser matéria de poesia, não restaria ao poeta senão repetir indefinidamente as soluções tradicionais; ou, então, a paralisação do impulso criativo. É isto que sugere Cláudio no "Prólogo":

“destinado a buscar a Pátria, que por espaço de cinco anos havia deixado, aqui, entre a grosseria dos seus gênios, que, menos pudera eu fazer que entregar-me ao ócio, e sepultar-me na ignorância!"

Mas, para o bem da poesia, isso não se realiza, e o poeta faz o poema, mesmo não tendo outra matéria-prima que a realidade bruta, marco zero da criação.

Finalmente, sentida uma ausência (a do modelo poético) e apontada uma presença (a da realidade brasileira), só resta ao poeta moldar o poético como expressão que transfigura o real, resgatando-o, ao mesmo tempo, do utilitário e do informe sem nome. É o que faz Cláudio no terceto final:

Que de seus raios o planeta louro

Enriquecendo o influxo em tuas veias,

Quanto em chamas fecunda, brota em ouro.

Isto é, as águas iluminadas pelo "planeta louro" projetam o referente histórico (o ciclo da mineração do século XVIII) sobre o plano metafórico das sensações estéticas como beleza puramente contemplada. É o modo de encontrar uma imagem capaz de dar conta do duplo significado da luz que, incidindo sobre o líquido, faz brotar tanto o ouro no seu sentido próprio de metal precioso (referente histórico) quanto o brilho das irradiações luminosas (valor estético). Dessa forma, o poeta concilia a percepção do real, motivo daquilo que ele chama "ambiciosa fadiga de minerar a terra" ("Prólogo"), com o desejo de despertar o prazer estético desinteressado. 
Concluindo, podemos dizer que Cláudio parte de uma posição que não admite a realidade como fonte de poesia. Apesar disso, sente-se ligado à terra ainda sem tradições. Nesse contexto, o adjetivo "turvo" não é mais um termo negativo, por oposição ao "cristalino" dos rios árcades, mas a diferença específica que separa da tradição poética portuguesa a emergente poesia brasileira: se aquela projetava o poético como um real fictício, isto é, convencional, esta precisa projetar o real, semantizado pela emoção, como valor e símbolo poéticos. Embora submetendo-se às imposições poéticas e culturais de seu tempo, o poeta encontra meio de falar do real que lhe absorve a atenção e expressa o sentimento.

\section{BIBLIOGRAFLA}

ADORNO, Theodor W. "Lírica e Sociedade" In: Walter Benjamin, Max Horkheimer, Theodor W. Adorno, Jürgen Habermas. Os Pensadores. São Paulo, Abril, 1980.

ASSIS, Machado. Obra Completa. Rio de Janeiro, AGUILAR, 1962. 3v.

AZEVEDO FILHO, Leodegário Amarante de. Anchieta, a Idade Média e o Barroco. Rio de Janeiro, Gernasa, 1966.

BOSI, Alfredo. Dialética da Colonização. São Paulo, Companhia das Letras, 1992. BURKE, Peter(1993). A Arte da Coversação. São Paulo, UNESP, 1995.

CAMINHA, Pero Vaz de. Carta a El Rei D. Manuel. São Paulo. Domus, 1963.

CAMÕES, Luis de. Os Lusiadas. 12a. ed. São Paulo, Melhoramentos, s/d.

CANDIDO, Antonio. "No limiar do novo estilo: Cláudio Manuel da Costa" In: Formação da Literatura Brasileira (Momentos Decisivos). São Paulo, Martins, 1964. 2v.

CANDIDO, A. e CASTELLO, J. A. Presença da Literatura Brasileira. 5a. ed. São Paulo, Difusão Européia do Livro, 1973. 3v.

CASTELLO, Aderaldo. Manifestações Literárias da Era Colonial. São Paulo, Cultrix, 1969.

CURTIUS, Ernst Robert. Literatura Européia e Idade Média Latina. Rio de Janeiro, MEC-INL, 1957.

DÍAZ-PLAJA, Guillermo. Antologia Mayor de la Literatura Hispanoamericana. 2 v. Barcelona, LABOR, 1969.

GAMA, José Basílio da (1769). O Uraguai. Edição comemorativa do Segundo Centenário anotada por Afrânio Peixoto, Rodolfo Garcia e Osvaldo Braga. Rio de Janeiro, Academia Brasileira de Letras, 1941.

GÂNDAVO, Pêro de Magalhães(1570). Tratado Descritivo da Província do Brasil. INL/MEC., 1965.

HOLANDA, Sérgio Buarque de (1936). Raizes do Brasil. Sa. ed., Rio de Janeiro, José Olympio, 1967. 
(1959). Visão do Paraiso. Os motivos edênicos no descobrimento do Brasil. São Paulo, NACIONAL/EDUSP, 1969.

Capitulos de Literatura Colonial. Org. e Intr. de Antonio Candido.

São Paulo, Brasiliense, 1991.

IMBERT, Enrique Anderson(1954). Historia de la literatura hispanoamericana.

2v. I Colonia - Cien años de República. México, Fondo de Cultura Económica, 1961.

MARTINS, Wilson. História da Inteligência Brasileira. Vol. I (1550-1794). $3 \mathrm{a}$. ed. São Paulo, Cultrix, 1978. 5v.

MONTAIGNE, Michel de(1580). Ensaios. Trad. Sérgio Milliet. São Paulo, Os Pensadores XI, 1972.

OLIVEIRA, Manuel Botelho de(1705). Música do Parnaso. Prefácio e organização do texto por Antenor Nascentes. Rio de Janeiro, MEC/INL., 1953. 2 t.

PESSOA, Fernando. Obra Poética. Rio de Janeiro, Aguilar, 1960.

PEIXOTO, Alvarenga. Vida e Obra de Alvarenga Peixoto. Manuel Rodrigues Lapa. Rio de Janeiro, INL/MEC, 1960.

PETRARCA, Francesco. Canzoniere. Novara, Inst. Geografico de Agostini, 1962. PINTO, Bento Teixeira(1601). Prosopopéia. Introdução, estabelecimento de texto e comentários por Celso Cunha e Carlos Durval. Rio de Janeiro, Melhoramentos/INL., 1977.

PRADO Jr., Caio(1933). Evolução Politica do Brasil e Outros Estudos. São Paulo, Brasiliense, 1969.

PROENÇA FILHO, Domício(org.). A Poesia dos Inconfidentes. Poesia Completa de Cláudio Manuel da Costa, Tomás Anônio Gonzaga e Alvarenga Peixoto. Rio de Janeiro, Nova Aguilar, 1996.

RAMOS, Péricles Eugênio da Silva. Poemas de Cláudio Manuel da Costa. São Paulo, Cultrix, 1966.

ROUANET, Maria Helena. Eternamente em Berço Esplêndido. A Fundação de uma Literatura Nacional. São Paulo, Siciliano, 1991.

SAPIR, Edward. "Língua, Raça e Cultura" In A Linguagem. Introdução ao Estıdo da Fala. Rio, Acadêmica, 1971.

SARAIVA, António José e LOPES, Óscar(1955). História da Literatura Portuguesa. 7a. ed. Santos, Martins Fontes, 1973.

SOUSA, Gabriel Soares de(1587). Tratado Descritivo do Brasil. 4a. ed. São Paulo, Nacional/Edusp, 1971.

VERÍSSIMO, José. História da Literatura Brasileira, 3a. ed.. Rio de Janeiro, José Olympio, 1954.

VICO, Giambattista(1744). La scienza nuova. Roma-Bari, Laterza, 1974. 2v.

UREÑA, Pedro Henriquez(1947). Historia de la Cultura en la América Hispánica. México, Fondo de Cultura Económica, 1959. 

n. 22, p. 201-219, 1996.

\begin{abstract}
This article tries to illustrate how the first colonists who wrote about Brazil saw it from their own experience, projects and values. If at first our poets assumed their Metropolis" cultural and literary identity, they would through time, develop a new sensibility associated to new ways of seeing and feeling their relationship with the environment, whose consequences would reflect in the poetry produced here.
\end{abstract}

Key-Words: Literature and colonization, brazilian poetry. 